\title{
Religion as Factor in Formation of Law: Current trends
}

\author{
Erwin Akhverdiev*, Alexander Ponomarev ${ }^{1}$ \\ ${ }^{1}$ Volgograd State University, Faculty of Law, 400062 Volgograd, Universitetskiy prospect 100, Russia
}

\begin{abstract}
This article consists of the following parts: introduction, methodology, research results, analysis, and discussion. The article is devoted to religious law formation research from a historical and modern prospective. The authors consider the most prevalent religions in present-day society such as Hinduism, Christianity, Islam, and Buddhism and the way in which these religions influence legislation of India, Russia, Thailand, the United Kingdom and Muslim states. Furthermore, the author researches relationship between religion, law, and morality to reveal theoretical and practical links between religion and law. The explanation of the criteria for the legal provisions morality of is an obvious fact. In this regard, analysis of religious values and morality mutual influence is a necessary step of scientific research. This point provided a basis for studying the basic tenets of Christianity, Islam, Hinduism, and Buddhism in terms of their ability to determine law. In conclusion, the authors note that the search for the rule we are looking for is not absolute, and many lawyers denied the very possibility of its existence. However, the authors come to the conclusion that complete denial of religious determinism of law restricts the range of possible tools for studying law formation.
\end{abstract}

\section{Introduction}

The expression "formation of law" is used to denote the law emergence process as one of the most important social phenomena [1]. Law itself is a phenomenon that is inseparable from modern society. In this regard, law emergence and formation is impossible without specific social processes and conditions. Cicero noted this in his famous papers, where he wrote "Ubisocietas, ibijus" (lat. - wherever there is society, there is law) [2]. It should be noted that in addition to law, religion plays a particularly significant role in social processes. If the law regulates socially significant relations, then religion permeates almost every area of human life, invading the sphere of morality. However, in this connection, the question arises: if religious doctrines and tenets are deeply rooted in society, do they influence the emergence and formation of law?

\section{Methodology}

Research methodology for this article is represented by social and cultural approach, including comparative legal methods, methods of analysis and interpretation. These tools are considered to assess legal provisions susceptibility to religious principles influence. The object of the study is public relations in the sphere of legislative bodies of certain states and religious systems. The subject of the study is mutual influence of legal and religious provisions in regulation of social processes. It is worth noting that such approach to law formation is not something new for the legal science. Specific studies were conducted by both domestic and foreign lawyers. Among them are Thomas Aquinas, Hugo Grotius, Georg Hegel, Ilya Berdnikov, Nikolai Korkunov, Lev Petrazhitsky, Alexei Kuprianov and other authoritative researchers. But nowadays the problem arisen is specifically acute in terms of necessity to determine and assess legal provisions effectiveness. Such necessity is predetermined by increased multiplicity and inconsistency of laws.

\section{Analysis}

The analysis shows that religious values and tenets are reflected in both historical development of legal provisions and in modern society. Interim conclusion is that the legal provision as the main social relations regulator, requires not only the strength of state coercion but also some sacredness. It should be noted that most frequently links between religious dogmas and law are found in forensic science. In addition, a fairly obvious influence of Christian and Muslim teachings can be found in civil law, constitutional law and even politics and economics of particular states. In this regard, it is necessary to conduct comprehensive study of the specifics of Russian law-making and legislative process in relation to religious principles, taking into account the recognition of religion as a universal value in terms of globalization and legal systems approximation.

To begin with, it would be wise to consider the relationship between religion, morality, and law. Morality is an integral and fundamental part of any religion we cannot separate from the whole analysis. The task of 
correlating the above-mentioned social phenomena has always been an acute discussion topic in the history of philosophy, culture, and legal science. Religious ideologists believe that neither morality nor law can exist without religious foundation [3]. The opposite point of view is reflected in the works of Roman philosophers. For instance, Lucretius noted that religion was capable to beget wicked and criminal deeds [4]. Indeed, in this aspect, theodicy as the justification of God becomes particularly important as a goal and purpose in many creeds. The complicated and sometimes contradictory nature of the relationships between religion and morality resulted from differences between these two phenomena. The main distinction is that morality is the path to goodness and moral values, improving human nature itself, and religion is the way to God and worship.

Certainly, these features of social regulators may coincide but in history there are many examples where they differ significantly. In this regard, it is useful to recall the struggle of Catholicism with heresies and the Inquisition in the period between the 13th to the 19th centuries, which killed several million people. Moreover, the Crusades which established faith on the conquered lands are significant historical example [5]. Sigmund Freud noted this phenomenon in his papers where he wrote that immorality and morality find support in religion in equal way [6].

At the same time, religion and morality have tough links between each other. It can be expressed in the fact that these links are impregnated by ethic issues of moral consciousness such as onus, justice, guilt. Russian religious philosopher Vladimir Soloviev evenly noted that religion and morality influenced each other in equal way [3].

Another apparent point is that such social phenomena as morality and law emerge gradually. They are not a product of a ready-made way. In spite of their different existence conditions, it is possible to light out some aspects that bring them closer [7]. For instance, the Article 2 of the Constitution of the Russian Federation claims, "Man, his rights and freedoms are the supreme value. The recognition, observance and protection of the rights and freedoms of man and citizen shall be the obligation of the State" [8]. Moreover, the second chapter of the Constitution contains citizens' fundamental rights and obligations. System analysis of these provisions shows that their main content is universal values, which consist in close connection with ethics of morality and religion in their essence. In addition, assessment function brings religion, morality, and law together, because it is peculiar for them all. The assessment function for morality and religion is public opinion and conscience. In case of law, this function is represented by court and legal consciousness of society.

In addition, religion, morality and law have essential function of creating conditions for the establishment of stability in society and prerequisites for the person to realize his or her needs to the extent that they do not conflict with the interests of other people. Famous American lawyer Harold Berman represented interesting classification, where he identified four ways in which the law performs this function:
1. The application of the ritual, expressed in some procedures that guarantee and assure society of objectivity and impartiality - for example, the administration of justice.

2. Tradition, which demonstrates continuity and stability and symbolizes binding force of law.

3. Use of credibility based on trust which symbolizes the fairness of established legal provisions, and use of state coercion force.

4. Universality which expresses claims of law to verity in regulation of specific legal relationships, thus becoming the response to any situation a person may face [9].

It is noteworthy that presented ways of conducting function mentioned above are inherent to any of the world religions that exist today and used by them all.

While considering relationships between religion and law more carefully, it is worth highlighting the fact that they make certain demands on public relations and establish rules of behavior simultaneously. The fact is that the rules formulated by religion are also imperative in order to influence people's lives, although by means of specific methods [10].

\section{Discussion on national and world religions}

\subsection{Hinduism}

The next level of analysis shows particularly how religious standards influence law formation. In this regard, the first obvious example is the Hinduism teaching. This teaching, being one of the most proliferated national religions, is common in India.

Thus, Hinduism developed the doctrine of three goals of human life:

1. Dharma (law, duty, ought) as the need to comply with the rules in order to maintain order and stability;

2. Artha (benefit associated with social life) as governor's responsibility for the well-being of his citizens and their wealth;

3. Kama as love and human's sensual pleasure [11].

Good and evil in Hinduism are determined through human behavior and its compliance and conformity to dharma. This religious movement influenced the ethical and legal traditions of society greatly. Religious precepts "dharmasastra" and "arghashastra" served as the main source for the ancient Indian law formation. Therefore, for example, "Laws of Manu" means "Manu's sermon on dharma" in literal translation. In this treatise, there are close relationships between law and religion that expresses itself in the absence of clear differentiation of delicts and crimes. "Manu Laws" enshrined social order based on Hinduism. For example, the property of the Brahmins, who were highest varna representatives, was untouchable even by state governor [12]. In addition, a clear caste system was secured. Nowadays India's legislation prohibits caste discrimination, but some rules transferred and consolidated in family relations as traditions and customs [13]. 


\subsection{Buddhism}

Another important and most widespread religion is Buddhism. According to the basic tenets of this teaching, there is the "Noble Eightfold Path", which includes the eight conditions of right existence:

- Right view

- Right resolve

- Right speech

- Right conduct

- Right livelihood

- Right effort

- Right mindfulness

- Right contemplation (Samadhi).

Among of numerous basic demands, Buddhism requires a person not to harm, not to hurt, to refrain from lying, obscene speech, and taking life. In addition, this teaching requires exercising will and minding. Reason and intelligence play a significant role in Buddhism as a criterion of justice in law. In such case, reason is an obligation to respect law, since it is the law that manifests itself in wise measures and brings people goodness. According to the ancient "Jataka tales" (the arch of Buddhist legends), law forces people to be resolute, persistent and able to rise above their selfish goals [14]. To some extent, most of these rules one can see while considering lawfulness of those people who manifests Buddhism. In some countries, Buddhism is the state religion - for example, in Thailand. It is resulted in the fact that up to the 19th century the ancient Thai law based on the "Laws of Manu" was the main source of law. Currently, the legal provisions in Thailand are very complicated and severe in terms of punishment. Along with that, numerous special state bodies supervise punishment execution extremely carefully.

\subsection{Christianity}

Subsequent analysis is connected with Christianity influence in those countries where it is the common religion. Its wide dissemination is very important to be realized. Christianity is the most widespread religion in the world. The teaching is quite complicated and difficult for detailed research because Christianity includes various religious denominations - Orthodoxy, Protestantism, Catholicism, Lutheranism, and so on. However, it seems possible to identify some common definitions that correspond to Christianity in general.

Another important feature is dogmatism of the Christian teaching. Christian tenets are stable and constant in their essence. That is why many theologians can define Christian morality as a system of moral norms, feelings, and behavior closely associated with these tenets. The source of first moral ideals is the Jesus Christ's "Sermon on the Mount". Notably, the moral norms contained in the Sermon differ from the Buddhist and Hindu ones greatly. For example, the "Sermon on the Mount" excluded the talion principle already established in many societies. Love for an enemy replaced talion because only God fulfills the mission of revenge [15]. Thus, love for God and love for human become the main precept [16].
Correlating these basic values with the law one can find out that they gave birth to humanism principle which nowadays prevails in many state legal systems.

While assessing the role of Christianity in Russian law, turning to the period of emergence of first law codes is very important. The main source is the "Russkaya Pravda" (the "Rus law") which contained provisions on criminal and private law, as well as certain procedural rules. Christian tenets definitely became one of the main sources for the "Rus law". Some precepts as "do not kill", "do not steal", "do not commit adultery", "do not lie" were reflected in the first Russian law in one form or another. Further, religious values and percepts had been acting as a basis for the main laws of the Ancient Rus and the Russian Empire. They allowed watching the connection between religion and law for a long time.

Russian public and state figure Mikhail Speransky noted this phenomenon when working on the Civil Code Project in 1845. Emphasizing that God is the "eternal lawmaker of the universe," he believed that the goal of law moral justification was the harmonization of legal concepts with the Christian postulates [17]. Vladimir Soloviev, while developing his philosophy of law conception, wrote that law was the minimum limit and a certain minimum of morality formed from Christianity [18].

\subsection{Judaism}

It is known that the main teaching treatise for the Jews is the Torah (the first five books of the Hebrew Bible, sometimes referred to as "the Five Books of Moses").

The Torah is the foundation of Judaism and its part named Halakha is a collective body of Jewish law deprived from the Oral and Written Torah. There can be a questionable problem while studying influence of Judaism in Jewish law because Halakha and its content differs in numerous Jewish communities such as Ashkenazi, Mizrahi, Sephardi, Yemenite. But it's possible to find some common features. The word Halakha is usually translated as "Jewish Law", although a more literal (and more appropriate) translation might be "the path that one walks." After certain period of time the word Halakha began to be used to describe the whole legal and religious Judaism system. In other words, Halakha is the full way the real Jew should behave in day-to-day life what you do when you wake up in the morning, what you can and cannot eat, what you can and cannot wear, how to groom yourself, how to conduct business, who you can marry, how to observe the holidays and Shabbat, and perhaps most important, how to treat God, other people, and animals.

The real Jew should observe all the 613 tenets (mitzvot) written in the Torah. But there are The Seven Laws of Noah which can be described as the minimum values that should be observed and respected by everyone, not only by the Jews. These are the basic Judaism values:

- Not to worship idols

- Not to curse God

- To establish courts of justice

- Not to commit murder 
- Not to commit adultery or sexual immorality

- Not to steal.

- Not to eat flesh torn from a living animal [19]. It should be noted that the full 613 tenets of the Halakha given in the Torah touch every aspect of human life and regulate them in a very strict manner. As Izhak Englard notes, "in Israel a number of religious bodies exercise official functions; the religious law applied in limited areas; a religious educational system makes a part of public education; there is a governmental department for the religious affairs, and the State finances religious matters" [20]. In this regard, approaches to influence of the Jewish law on secular law and formation of the Israeli state itself can be divided into national-secular and religious one. According to the first approach, there should be selective reception of traditional Halakha laws that would be relevant and acceptable in modern society. The second one insists on establishing Halakha as the religious foundation for the formation of law. This point is a very acute and disputable issue until the present days in Israeli society.

Noteworthy, in modern Israel the Torah and the Talmud are recognized as one of the sources of civil law that courts rely on including interpretation the application of legislation enacted by the Israeli parliament - Knesset. On November 10, 2009, Israeli Minister of Justice Yaakov Naaman noted that the authorities would gradually give the citizens of Israel the laws of the Torah and make Halakha the main law of the country [21].

A significant feature of modern Israeli legal system is inclusion of Halakha into secular law despite Israeli law is no way equal or identical to religious one. Personal status is the only area in which religious law was fully incorporated [22]. Acts of civil status (marriage, divorce, burial) are under the jurisdiction of religious courts (Jewish, Muslim, Druze and Christian). The jurisdiction of the rabbinical courts also includes the assertion of the Gyur [22].

The Halakha influence on modern Israeli law is also connected with the aspiration of society to find compromise acceptable for both religious and nonreligious movements. Moreover, natural aspiration to preserve national traditions and religion in public life of the country resulted in so-called status quo that developed before the emergence of the Jewish state. According to this, there is the jurisdiction of rabbinate courts in the field of personal status and divorce of members of the Jewish community, the prohibition of work on Saturday (Shabbat), the days of religious holidays in state institutions and public institutions, public transport, industrial enterprises and in the service sector; prohibition to publicly sell leaven (chametz) in Pesach; a special network of religious schools; religious institutions and services recognition funding. Also important that the Halakha principles partially influenced immigration legislation (for instance, Law of Return).

At the present time, when the court needs to take a decision on an issue it searches for a solution among the laws of the State of Israel, then among the laws of the British Mandate, and in the next turn among the Jewish primary sources (Talmud, Halakha, and etc.).

\subsection{Islam}

The wording "Muslim law" itself means greatest interweaving of Islamic traditions and tenets in the legal system of countries in which this religion is a state or prevailing one. The principal and sacred source of teaching for the Muslims is the Quran.

The peculiarity of this Holy Scripture is that it connects moral norms with other means of regulation of social relations such as religious ritual, customary law, and legal code [23]. A true Muslim's rules of behavior are regulated by Sharia. Sharia includes law, moral worldview, cult beliefs and precepts [24]. According to Sharia, there are the following kinds of acts of Muslims:

- Mandatory acts (fard) - for example, a fivefold prayer;

- Desirable acts (mustahabb) - praiseworthy deeds unfulfillment of which is not punishable (for example, forgiveness of offenders, deterrence of anger);

- $\quad$ Allowed acts (halal, jaiz) - such deeds are resolved and they do not entail either approval or censure;

- Unworthy acts (makruh) - unacceptable deeds, but also non-punishable (for example, extravagance, stinginess);

- Forbidden acts (mahzur) - acts and thoughts for which the Muslim will be punished (drinking wine, usury, etc.) [25].

All these kinds of deeds correlate with imperative and dispositive legal regulation methods distinguished in legal theory.

In addition, another point of interest is the essence of the gravest sins in accordance with the Quran: murder (abortion), suicide, disrespect for parents, adultery, homosexuality, usury, theft, and bribery [26]. Noteworthy, these sins have their legal form (directly or indirectly) in those countries where Islam is a state religion or a predominant one.

One of the visual examples of connection between Islamic tenets and law provisions is the mechanism of Islamic banking the foundation of which is the ban on usury. All the activity of such banks has legal registration in Muslim countries. Moreover, it should be noted that legislative base for Islamic banking is already being developed in Europe and other countries. The increase in the number of Muslims in Britain, France, Luxembourg, makes this expansion a discursive phenomenon. For instance, in England, double stamp duties have already been cancelled. The thing is that until recently these duties prevented the property purchase in accordance with Islamic principles [27]. In addition, the British legal society issued a guide for drafting Sharia law testaments because of increasing demand for such services.

These examples are not isolated but systematic and they show how much religious factor can determine emergence of law provisions even in modern society.

\section{Conclusion}

The interrelationships between different world and national religions and law show the possibility of their 
coexistence. On the other hand, it is difficult to believe that most of law provisions are determined by religious factor, especially under the conditions of law secularity. For example, same-sex marriages legalization in several European countries and some US states does not fit into religious tenets. In this regard, one can recall Immanuel Kant's philosophy of law. Famous philosopher in fact denied the participation of religion in the law formation process emphasizing that only morality is the real thing of importance [28]. In the theory of law, there are other opinions that justify different approaches. But in fact the possibility of religious factor influence on the legal sphere of human life cannot be completely ruled out.

\section{References}

1. A.V. Poliakov, Manual for students of Legal science (St. Petersburg University Press, 2004)

2. M.T. Cicero, Three books On the Orator, edited by M.P. Gasparov (Moscow, 1994)

3. L.A. Popov, Ten lectures on ethics: Student manual (Moscow, 2001)

4. T.L. Carus, On the Nature of Things (Book upon request, Moscow, 2012)

5. E.N. Gritsak, Short history of the Crusades (RipolClassic Short history Series, Moscow, 2002)

6. S. Freud, Introduction to Psychoanalysis (Science Press, Moscow, 1989)

7. V.D. Perevalov, Theory of the State and law: manual for bachelors (Uright Press, Moscow, 2014)

8. Constitution of the Russian Federation dated 12.12.1993

9. H.G. Berman, Faith and Order: The Reconciliation of Law and Religion (Wm. B. Eerdmans Publishing, 1993)

10. V.I. Garadzha, Social science of religion (Moscow, 2005)

11. L.S. Vasilyev, East religions history (Higher School Publishing, Moscow, 1988)
12. A.A. Kutsenkov, Evolution of Indian caste (Science Press, Moscow, 1983)

13. Jatakitales, translated by A.P. Baranova, O.F. Volkova (St. Petersburg, 1993)

14. Robert C. Lester, Buddhism: the Path to Nirvana (Harper \& Row, 1987)

15. Julius S. von Carolsfeld, The biblical encyclopedia: 240 prints (Olma-Press, Moscow, 2002)

16. I.S. Sventitskaya, Early Christianity: pages of history (Moscow, 2003)

17. I.V. Kireevskiy, Thought on the nature of European enlightment and its attitude to enlightment in Russia, Book 1 (Moscow, 1911)

18. V.S. Soloviev, Essays in 2 Books, Book 1 (Moscow, 1988)

19. J. Meri, the Routledge Handbook of Muslim-Jewish Relations (Taylor \& Francis London, 2016)

20. I. Englard, Amer. J. of Com. Law 35 (1987)

21. A. Jaulmes, Et si la Torah se substituait à la loi israélienne?(Le Figaro, 2009) Retrieved from http://www.lefigaro.fr

22. M.V. Baglai, Y.I. Leibo, F.M. Entin, Constitutional Law of Foreign Countries (Moscow, 2008)

23. A.A. Guseinov, Great moralists (Moscow, 2008)

24. L.G. Gornostaeva, G.A. Torgashev, Lectures on bases of religious science (RSJU Publishing, 2015)

25. M.A. Rodionov, Classic Islam (Petersburg oriental studies, St Petersburg, 2001)

26. A.A. Ali-zade, Main sins in Islam (http://mukmin.narod.ru/osgreh.html)

27. A.B. Orishev, Islam banking in Europe, Buss. and design 3 (2016)

28. I. Kant, Critique of Practical Reason (Science Publishing, St. Petersburg, 2007) 